\title{
Otyłość w okresie około- i pomenopauzalnym
}

\author{
Joanna Tkaczuk-Włach ${ }^{1}$, Rafał Włach ${ }^{2}$, Małgorzata Sobstyl ${ }^{1}$, Grzegorz Jakiel ${ }^{3}$ \\ ${ }^{1}$ Katedra i Klinika Ginekologii i Endokrynologii Ginekologicznaj Uniwersytetu Medycznego w Lublinie; \\ kierownik Katedry: prof. dr hab. n. med. Lechosław Putowski \\ ${ }^{2}$ Katedra i Zakład Zdrowia Publicznego, II Wydział Lekarski z Oddziałem Anglojęzycznym Uniwersytetu Medycznego w Lublinie; \\ kierownik Katedry i Zakładu: prof. zw. dr hab. n. med., dr h.c. Piotr Książek \\ 3) Klinika Położnictwa i Ginekologii Centrum Medycznego Kształcenia Podyplomowego w Warszawie \\ kierownik Kliniki: prof. dr hab. n. med. Grzegorz Jakiel
}

Przegląd Menopauzalny 2012; 6: 514-517

Dietetycy biją na alarm - otyłość stała się poważnym problemem medycznym. Wciąż wzrasta liczba osób, u których rozpoznaje się nadwagę lub otyłość. Epidemia otyłości dotyczy wszystkich grup wiekowych, w tym - co szczególnie niepokojące - także dzieci [1].

Otyłość definiuje się najczęściej za pomocą wskaźnika masy ciała (body mass index - BMI), który jest wynikiem podzielenia masy ciała przez wzrost $\mathrm{w}$ metrach do kwadratu. Kiedy BMI wynosi ponad $30 \mathrm{~kg} / \mathrm{m}^{2}$ rozpoznaje się otyłość, kiedy mieści się w przedziale $25-29,9 \mathrm{~kg} / \mathrm{m}^{2}$, mówi się o nadwadze.

W jednym z ostatnich raportów Światowej Organizacji Zdrowia (World Health Organization - WHO) w 2008 roku 1,5 mld osób w wieku powyżej 20. roku życia, zarówno w krajach rozwijających się, jak i rozwiniętych, miało nadwagę. $Z$ tego ponad $200 \mathrm{mln}$ mężczyzn i ok. $300 \mathrm{mln}$ kobiet było otyłych [2]

Otyłość ma złożoną etiologię. Jej rozwój może wiązać się z zaburzeniami układu nerwowego czy zaburzeniami hormonalnymi, z zażywaniem określonych leków, wreszcie z zaburzeniami warunkowanymi genetycznie. Najczęściej spotykana jest tzw. otyłość prosta, której etiologia wiąże się z wpływem zarówno czynników dziedzicznych, jak i środowiskowych, takich jak styl odżywiania, życia, czynniki psychologiczne, socjalne czy metaboliczne [3].

Badania przeprowadzone na dużej liczbie kobiet w Iranie dostarczyły wyników wskazujących, że niski poziom aktywności fizycznej i edukacji, wywiad obciążony rodzinnym występowaniem otyłości, urodzenie pięciorga i większej liczby dzieci czy zawarcie małżeństwa w młodym wieku wpływa na zwiększone ryzyko otyłości wśród kobiet - zwłaszcza typu brzusznego [4]. Powyższe badanie potwierdza teorię o wieloczynnikowej etiologii otyłości i każe o niej myśleć jako o złożonym procesie trudno poddającym się leczeniu.

Dodatni bilans energetyczny będący wynikiem nadmiernej podaży pokarmów, któremu towarzyszy zmniejszony wydatek energetyczny, kojarzony jest tradycyjnie z rozwojem otyłości. Jednak istnieje coraz więcej badań potwierdzających wpływ innych czynników na rozwój otyłości, jak np. zakłócenie rytmu i czasu spożywania pokarmów wynikające np. z pracy zmianowej i towarzyszących im zakłóceń snu, pomijanie śniadań, zbyt duża częstotliwość spożywania positków w ciągu dnia, nieregularność positków, spożywanie fast foodów czy dań na wynos oraz zbyt dużych porcji i najadanie się do syta [5-7].

Wyróżnia się dwa typy otyłości: typ gynoidalny z przewagą tkanki tłuszczowej w okolicy pośladków i ud oraz typ brzuszny z przewagą tkanki tłuszczowej w okolicy tułowio-brzusznym, w którym wskaźnik talia/biodro (waist to hip ratio - WHR) wynosi dla kobiet 0,8 , a dla mężczyzn powyżej 1. Rozpoznanie otyłości typu brzusznego ma swoje znaczenie kliniczne, ponieważ jej występowanie jest jedną z cech kwalifikujących do rozpoznania zespołu metabolicznego. Wskaźnik talia/biodro jest często używany w badaniach epidemiologicznych, jest przydatny w ustalaniu proporcji między tłuszczem zgromadzonym w górnej oraz dolnej części ciała, nie daje jednak podstaw do oceny, czy tłuszcz zlokalizowany jest podskórnie, czy wisceralnie [8]. Dopiero badania obrazowe, $w$ tym tomografia komputerowa (TK), pozwalają na różnicowanie między obecnością tłuszczu w tkance podskórnej czy obszarze trzewnym. Ma to istotne znaczenie w badaniach np. nad zespołem metabolicznym. Wiele prac potwierdziło niekorzystny wpływ otyłości brzusznej i depozytu tłuszczu w głębokich warstwach jamy brzusznej (tzw. tłuszczu wisceralnego) na procesy metaboliczne. Ilość wisceralnej tkanki tłuszczowej koreluje z wieloma klinicznymi wykładnikami zespołu metabolicznego, tj. nietolerancją glukozy, nadciśnieniem, insulinoopornością czy dyslipidemią arterogenną, rozumianą m.in. jako zwiększenie stężenia trójglicerydów i zmniejszenie stężenia lipoprotein o dużej gęstości (high density lipoprotein - HDL) w surowicy [8-11].

Otyłość zwiększa ryzyko wystąpienia wielu chorób, m.in.: cukrzycy typu 2, choroby niedokrwiennej serca, zawału mięśnia sercowego, miażdżycy naczyń, nadciśnienia tętniczego, udaru mózgu, nietrzymania moczu, 
zespołu otępiennego, choroby zwyrodnieniowej stawów czy wreszcie - nowotworów, w tym raka sutka, endometrium i jelita grubego [1, 2].

Bogate jest piśmiennictwo potwierdzające negatywny wpływ otyłości na pogorszenie tzw. jakości życia (health-related quality of life - HRQOL). Otyłość wpływa na obniżenie sprawności fizycznej, zmianę wyglądu, pogorszenie samooceny ogólnie rozumianego funkcjonowania społecznego. Płeć czy czynniki etniczne nie różnicowały w sposób istotny powyższych wyników [1]

\section{Ołyłość menopauzalna}

Dla populacji kobiet w wieku 55-65 lat wzrost masy ciała jest jednym z ich wiodących problemów zdrowotnych. Występowanie otyłości brzusznej jest prawie dwukrotnie częstsze niż otyłości ogólnej i jej częstość rośnie wraz z wiekiem kobiet. Wyniki badań z USA z 2008 r. oceniają ją na 65,5\% wśród kobiet w wieku 40-59 lat i na 73\% wśród kobiet po 60. roku życia [12].

Wielu autorów skupia się na poszukiwaniu ewentualnych przyczyn czy zwiększonej tendencji do otyłości pojawiającej się $w$ okresie menopauzy. Wymienia się tutaj wiele potencjalnych czynników, a wśród nich zwraca się uwagę na zaburzenia czynności podwzgórze-przysadka-tarczyca i związany z nimi stan względnej hipotyreozy. Wiele badań rzuca również nowe światło na rolę czynników ośrodkowych (głównie podwzgórzowego systemu kontroli łaknienia) czy wreszcie - rolę leptyny [3].

Leptyna jest hormonem wydzielanym przez tkankę tłuszczową. Jego stężenie koreluje z ilością tkanki tłuszczowej w organizmie. Przyjmuje się, że leptyna ma za zadanie hamować łaknienie i nasilać procesy termogenezy w przypadku nadmiaru tkanki tłuszczowej. Pełni więc funkcję czynnika sygnalizującego strukturom mózgowia ilość tkanki tłuszczowej, przez co przyczynia się do utrzymywania jej na stałym poziomie [13].

Stężenie leptyny stale się zwiększa w surowicy dziewcząt w okresie pokwitania w odróżnieniu od chłopców, u których zwiększa się w początkowej fazie dojrzewania. Później ta tendencja zanika, co sugeruje hamujący wpływ androgenów na wydzielanie leptyny [14]. Owariektomia u dorosłych samic szczurów powoduje znaczące zmniejszenie stężenia leptyny w surowicy, co jest odwracalne za pomocą suplementacji estrogenami. Estradiol nasila w warunkach in vitro produkcję leptyny przez komórki z tkanki tłuszczowej sieci pochodzącej od kobiet, jednak w tych od mężczyzn już nie. Stężenia estradiolu i testosteronu korelują ze stężeniami leptyny w surowicy kobiet dojrzałych [15].

Istnieją pewne rozbieżności co do teorii wpływu ewentualnego zmniejszenia stężenia leptyny w surowicy kobiet po menopauzie na rozwój otyłości pomenopauzalnej. Jedni autorzy opisywali zmniejszenie leptyny w tym okresie życia kobiet, inni nie znajdowali takich zależności [16-19]. Jeszcze inne publikacje opisują sytuację odwrotną - zwiększenie stężenia leptyny w surowicy kobiet w okresie pomenopauzalnym, czego z kolei nie zauważono w grupie stosującej hormonalną terapię zastępczą (HTZ) [20]. Podsumowując, ewentualna rola leptyny w powstawaniu otyłości menopauzalnej pozostaje dość enigmatycznym zagadnieniem i wymaga dalszych badań.

Innymi dyskutowanymi czynnikami mogącymi się przyczyniać do otyłości menopauzalnej są m.in. rozregulowanie mechanizmów odpowiedzialnych za apetyt na poziomie podwzgórza, np. przez zwiększenie działania galaniny stymulującej spożywanie tłuszczów, zmniejszenie wydzielania hormonu wzrostu, zmiany aktywności lipazy lipoproteinowej czy zmiany w równowadze między receptorami $\alpha$ - i $\beta$-adrenergicznymi w tkance tłuszczowej.

Podobnie dyskutowanym problemem jest ewentualny wpływ zmian stężeń hormonów płciowych na rozwój otyłości pomenopauzalnej. Już okres okołomenopauzalny, kiedy pojawiają się początkowo dyskretne objawy niedomagania jajników, jest związany z nagłym wzrostem masy tłuszczowej i jej redystrybucją w okolicę brzuszną [21].

Porównywano ilość tkanki tłuszczowej za pomocą absorpcjometrii promieniowania $\mathrm{X} w$ grupie kobiet w okresie okołomenopauzalnym i pomenopauzalnym oraz kobiet przed okresem menopauzy i stwierdzono w dwóch pierwszych grupach znaczący statystycznie wzrost ogólnej ilości tkanki tłuszczowej, szczególnie w okolicy górnej części ciała, a obniżenie jej ilości w okolicy ud [22]. Stwierdzono również zmniejszenie beztłuszczowej masy ciała.

Badania obrazowe potwierdzają $u$ kobiet po menopauzie większą ilość tkanki tłuszczowej w okolicy brzucha w porównaniu z kobietami w wieku przedmenopauzalnym $[23,24]$.

Wpływ stężeń hormonów płciowych i ich rola w rozwoju otyłości po menopauzie wymaga jeszcze dalszych badań. Istnieją też i takie opinie, które za dominującą przyczynę wzrostu masy ciała występującego po menopauzie uważają raczej proces starzenia się organizmu niż wpływ statusu hormonalnego wynikającego z menopauzy.

\section{Ołyłość a dolegliwości zwiq̨zane z menopauzq}

Otyłość jest niezależnym czynnikiem ryzyka rozwoju bardziej intensywnych objawów manopauzy $[25,26]$.

Tymczasem redukcja wagi i obniżenie BMI u kobiet z nadwagą czy otyłych wiąże się ze zredukowaniem objawów wazomotorycznych charakterystycznych dla okresu menopauzy [27].

Kobiety z większym BMI tracą masę kostną dużo wolniej w przebiegu menopauzy [28]. Jednak otyłość 
nie jest już czynnikiem zmniejszającym ryzyko złamań w grupie kobiet pomenopauzalnych [29].

Otyłe kobiety w wieku pomenopauzalnym, o czym już wspominano, doświadczają obniżenia jakości życia w wielu wymiarach. Pacjentki te zgłaszają częściej obniżenie energii życiowej i znaczące utrudnienia natury fizycznej ograniczające komfort codziennego funkcjonowania [30]. Towarzyszący otyłości stres psychiczny, wynikający z niskiej samooceny, może być szczególnie nasilony u kobiet. Wiąże się to z wpływem czynników kulturowych i ogólnym trendem promującym bardzo szczupły typ sylwetki. Wiele badań populacyjnych potwierdza związek między depresją a otyłością. Opisuje się np. dodatnią korelację miedzy cukrzycą typu 2 a rozwojem depresji. Innym wymiarem problemu jest tendencja u kobiet zagrożonych depresją do spożywania większych ilości pokarmu czy zmniejszenia aktywności fizycznej. Okres okołomenopauzalny związany jest z większą tendencją do rozwoju depresji, która spada po przebyciu menopauzy [31]. W jednym z ostatnich badań przeprowadzonych wśród młodych kobiet w wieku przedmenopauzalnym, ale $z$ depresją $w$ wywiadzie, stwierdzono znamiennie częściej zwiększony BMI, tendencję do otyłości brzusznej oraz zagrożeń zdrowotnych z tym związanych [32].

Menopauza $u$ kobiet otyłych często nasila objawy nietrzymania moczu. W tej grupie kobiet często obserwowane są również zaburzenia seksualne. Stwierdzono, że istnieje odwrotna korelacja między BMI a osiąganiem podniecenia, orgazmu czy właściwej lubrykacji [33]. Wśród otyłych kobiet w wieku pomenopauzalnym z otyłością typu brzusznego odsetek uskarżających się na problemy seksualne jest znacząco wyższy [34].

Jak wykazały badania na dużej populacji kobiet, stosowanie HTZ nie wiąże się z ryzykiem zwiększenia wagi, wręcz odwrotnie - zapobiega ona narastaniu depozytu tłuszczowego w okolicy brzusznej [35]. Terapia zastępcza, szczególnie ta przezskórna, ma jeszcze inne walory - redukuje insulinooporność i hiperinsulinizm, zmniejsza ryzyko rozwoju cukrzycy typu 2 [36].

\section{Zalecenia}

Regularny wysiłek fizyczny wpływa na ograniczenie wzrostu masy ciała i minimalizuje zmiany w składzie i rozmieszczeniu tkanki tłuszczowej, które zachodzą po okresie menopauzy. Zwrócenie uwagi na odpowiednią dawkę aktywności fizycznej w tym okresie życia zapobiega również wynikającym m.in. z otyłości brzusznej tendencji do rozwoju chorób serca, miażdżycy i cukrzycy. Dlatego ważne jest, aby lekarze przekonywali kobiety już w wieku przedmenopauzalnym do regularnej aktywności fizycznej, rozumianej jako 150 min umiarkowanej aktywności fizycznej w tygodniu lub 60 min umiarkowanego wysiłku dziennie [37, 38].

Ograniczenie spożywanych kalorii ma szczególne znaczenie w utrzymaniu lub powrocie do wagi pożądanej.
Ideałem jest jednak połączenie odpowiedniej niskokalorycznej diety i wysiłku fizycznego, co w kooperacji może dać znaczący spadek wagi. Jak wykazują badania, już spadek wagi większy niż 5\% masy wyjściowej działa profilaktycznie i obniża ryzyko związane z chorobami serca, dyslipidemią, nadciśnieniem czy cukrzycą [39]. Powszechnie przyjętą opcją idealną jest docelowe zmniejszenie masy ciała o $10 \%$ w tempie około 0,5-1 kg tygodniowo.

U osób z BMI powyżej $30 \mathrm{~kg} / \mathrm{m}^{2}$ przyjmuje się konieczność wprowadzenia oprócz odpowiedniej diety oraz ćwiczeń fizycznych farmakoterapii. Leki stosowane w celu utraty wagi działają wielotorowo: zmniejszają apetyt, zwiększają poczucie sytości i poziom metabolizmu oraz wpływają ograniczająco na wchłaniane niektórych składników spożywanych z jedzeniem - najczęściej tłuszczów. Orlistat, sibutramina oraz rymonabant należą do najczęściej opisywanych specyfików zakwalifikowanych do leczenia otyłości. Obecnie jedynie orlistat, który jest inhibitorem lipazy trzustkowej, jest uważany za bezpieczny w długim stosowaniu. Sibutramina i rymonabant zostały wycofane ze względu na opisane przypadki działań niepożądanych w postaci zawału serca, udaru mózgu czy zaburzeń psychicznych [40].

Chirurgia bariatryczna jest metodą inwazyjną zalecaną u pacjentów z dużą otyłością, trudno poddającą się innym metodom leczenia. Istnieje kilka metod gastroplastyki. Udowodniono ich rzeczywistą skuteczność ocenianą jako utratę masy wynoszącą - w zależności od badań - 16-28,6\%. Ograniczeniem tych metod jest jednak ich inwazyjność [41]. Dyskutowany jest również korzystny wpływ jogi, akupunktury czy ziół jako metod wspomagających działania dążące do obniżenia wagi [1].

\section{Podsumowanie}

Wydaje się, że w większości przypadków to świadoma zmiana trybu życia i nawyków żywieniowych doprowadza w dłuższej perspektywie do sukcesu w postaci obniżenia wagi oraz zmniejszenia ryzyka rozwinięcia wielu chorób towarzyszących otyłości, w tym zespołu metabolicznego. Uwaga skoncentrowana na kontrolowaniu wagi ma szczególne znaczenie u kobiet w wieku okołomenopauzalnym, ponieważ może to znacząco poprawiać komfort ich życia. Utrata zbędnych kilogramów poprzez indywidualnie dobraną dietę oraz ćwiczenia fizyczne, wprowadzenie zdrowych nawyków do codziennego życia może znacząco łagodzić dolegliwości związane z menopauzą.

\section{Piśmiennictwo}

1. Davis SR, Castelo-Branco C, Chedraui P, et al. Understanding weight gain at menopause. Climacteric 2012; 15: 419-29.

2. World Health Organization. Obesity and overweight. Fact sheet 2012; 311. http://www.who.int/mediacentre/factsheets/fs311/en.

3. Kos-Kudła B., Staszewicz P. Otyłość u kobiet w okresie około- i pomeno pauzalnym. W: Hormonalna terapia zastępcza. Skałba P (red.). Wydawnictwo Lekarskie PZWL, Warszawa 2005; 263-83. 
4. Hajian-Tilaki KO, Heidari B. Prevalence of obesity, central obesity and the associated factors in urban population aged 20-70 years, in the north of Iran: a population-based study and regression approach. Obes Rev 2007; 8: 3-10

5. Fonken LK, Workman JL, Walton JC, et al. Light at night increases body mass by shifting the time of food intake. Proc Natl Acad Sci USA 2010; 107: 18664-9.

6. Bezerra IN, Curioni C, Sichieri R. Association between eating out of home and body weight. Nutr Rev 2012; 70: 65-79.

7. Mesas AE, Muńoz-Pareja M, López-García E, Rodríguez-Artalejo F. Selected eating behaviours and excess body weight: a systematic review. Obes Rev 2012; 13: 106-35.

8. Wajchenberg BL. Subcutaneous and visceral adipose tissue: their relation to the metabolic syndrome. Endocr Rev 2000; 21: 697-738.

9. Després JP, Nadeau A, Tremblay A, et al. Role of deep abdominal fat in the association between regional adipose tissue distribution and glucose tolerance in obese women. Diabetes 1989; 38: 304-9.

10. Després JP. Abdominal obesity as important component of insulin-resistance syndrome. Nutrition 1993; 9: 452-9.

11. Laakso M, Sarlund H, Mykkänen L. Insulin resistance is associated with lipid and lipoprotein abnormalities in subjects with varying degrees of glucose tolerance. Arteriosclerosis 1990; 10: 223-31.

12. Flegal KM, Carroll MD, Ogden CL, Curtin LR. Prevalence and trends in obesity among US adults, 1999-2008. JAMA 2012; 303: 235-41.

13. Jéquier E. Leptin signaling, adiposity, and energy balance. Ann N Y Acad Sci 2002; 967: 379-88.

14. Clayton PE, Gill MS, Hall CM, et al. Serum leptin through childhood and adolescence. Clin Endocrinol (Oxf) 1997; 46: 727-733.

15. Paolisso G, Rizzo MR, Mone CM, et al. Plasma sex hormones are significantly associated with plasma leptin concentration in healthy subjects. Clin Endocrinol (Oxf) 1998; 48: 291-7.

16. Shimizu H, Shimomura Y, Nakanishi Y, et al. Estrogen increases in vivo leptin production in rats and human subjects. J Endocrinol 1997; 154: 285-92.

17. Rosenbaum M, Nicolson M, Hirsch J, et al. Effects of gender, body composition, and menopause on plasma concentrations of leptin. J Clin Endocrinol Metab 1996; 81: 3424-7.

18. Havel PJ, Kasim-Karakas S, Dubuc GR, et al. Gender differences in plasma leptin concentrations. Nat Med 1996; 2: 949-50.

19. Castracane VD, Kraemer RR, Franken MA, et al. Serum leptin concentration in women: effect of age, obesity, and estrogen administration. Fertil Steril 1998; 70: 472-7.

20. Di Carlo C, Tommaselli GA, Sammartino A, et al. Serum leptin levels and body composition in postmenopausal women: effects of hormone therapy. Menopause 2004; 11: 466-73.

21. Poehlman ET, Toth MJ, Gardner AW. Changes in energy balance and body composition at menopause: a controlled longitudinal study. Ann Intern Med 1995; 123: 673-5.

22. Genazzani AR, Gambacciani M. Effect of climacteric transition and hormone replacement therapy on body weight and body fat distribution. Gynecol Endocrinol 2006; 22: 145-50.

23. Toth MJ, Tchernof A, Sites CK, Poehlman ET. Menopause-related changes in body fat distribution. Ann N Y Acad Sci 2000; 904: 502-6.
24. Toth MJ, Tchernof A, Sites CK, Poehlman ET. Effect of menopausal status on body composition and abdominal fat distribution. Int J Obes Relat Metab Disord 2000; 24: 226-31.

25. Thurston RC, Sowers MR, Sternfeld B, et al. Gains in body fat and vasomotor symptom reporting over the menopausal transition: the study of women's health across the nation. Am J Epidemiol 2009; 170: 766-74.

26. Fernández-Alonso AM, Cuadros JL, Chedraui $P$, et al. Obesity is related to increased menopausal symptoms among Spanish women. Menopause Int 2010; 16: 105-10.

27. Huang AJ, Subak LL, Wing R, et al. An intensive behavioral weight loss intervention and hot flushes in women. Arch Intern Med 2010; 170: 1161-7.

28. Sowers MR, Zheng $\mathrm{H}$, Jannausch ML, et al. Amount of bone loss in relation to time around the final menstrual period and follicle-stimulating hormone staging of the transmenopause. J Clin Endocrinol Metab 2010. 95: 2155-62.

29. Compston JE, Watts NB, Chapurlat R, et al.; Glow Investigators. Obesity is not protective against fracture in postmenopausal women: GLOW. Am J Med 2011; 124: 1043-50.

30. Jones GL, Sutton A. Quality of life in obese postmenopausal women. Menopause Int 2008; 14: 26-32.

31. de Wit L, Luppino F, van Straten A, et al. Depression and obesity: a metaanalysis of community-based studies. Psychiatry Res 2010; 178: 230-5.

32. Cizza G, Ronsaville DS, Kleitz H, et al. Clinical subtypes of depression are associated with specific metabolic parameters and circadian endocrine profiles in women: the power study. PLoS One 2012; 7: e28912.

33. Pace G, Silvestri V, Gualá L, Vicentini C. Body mass index, urinary incontinence, and female sexual dysfunction: how they affect female postmenopausal health. Menopause 2009; 16: 1188-92.

34. Llaneza P, Ińarrea J, Gonzalez C, et al. Differences in health related quality of life in a sample of Spanish menopausal women with and without obesity. Maturitas 2007; 58: 387-94.

35. Norman RJ, Flight IH, Rees MC. Oestrogen and progestogen hormone replacement therapy for peri-menopausal and post-menopausal women: weight and body fat distribution. Cochrane Database Syst Rev 2000; (2): CD001018.

36. Bonds DE, Lasser N, Qi L, et al. The effect of conjugated equine oestrogen on diabetes incidence: the Women's Health Initiative randomised trial. Diabetologia 2006; 49: 459-68.

37. Sternfeld B, Dugan S. Physical activity and health during the menopausal transition. Obstet Gynecol Clin North Am 2011; 38 (3): 537-66.

38. Dugan SA, Everson-Rose SA, Karavolos K, et al. Physical activity and reduced intra-abdominal fat in midlife African-American and white women. Obesity (Silver Spring) 2010; 18: 1260-5.

39. Douketis JD, Macie C, Thabane L, Williamson DF. Systematic review of long-term weight loss studies in obese adults: clinical significance and applicability to clinical practice. Int J Obes (Lon) 2005; 29: 1153-67.

40. Ioannides-Demos LL, Piccenna L, McNeil JJ. Pharmacotherapies for obesity: past, current, and future therapies. J Obes 2011; 2011: 179674.

41. Picot J, Jones J, Colquitt JL, et al. The clinical effectiveness and cost-effectiveness of bariatric (weight loss) surgery for obesity: a systematic review and economic evaluation. Health Technol Assess 2009; 13: 1-190, 215-357.

Prawidłowe odpowiedzi do Testowego programu edukacyjnego dotyczącego otyłości w okresie około- i pomenopauzalnym, zamieszczonego w numerze 5/2012 Przeglądu Menopauzalnego:

1. d; 2. a; 3. d; 4. d; 5. d; 6. b; 7. d; 8. d; 9. d; 10. d; 11. a; 12. c; 13. d; 14. d; 15. d. 